Jurnal Teknologi Kimia Unimal 9:1 (November 2020) 46-57

\begin{tabular}{|ll}
\hline 45 Jurnal Teknologi Kimia Unimal & $\begin{array}{l}\text { Jurnal } \\
\text { Teknologi } \\
\text { Kimia } \\
\text { Unimal }\end{array}$ \\
\hline
\end{tabular}

\title{
PEMANFAATAN LILIN SARANG LEBAH SEBAGAI ANTIFUNGI PADA IKAN KAYU (KEUMAMAH) \\ Rozanna Dewi ${ }^{1)^{*}}$, Cut Nurwaida ${ }^{2)}$, Wusnah ${ }^{3)}$. Jurusan Teknik Kimia, Fakultas Teknik, Universitas Malikussaleh, Indonesia \\ Email: Nurwaidacut@gmail.com
}

\begin{abstract}
Abstrak
Ikan kayu (keumamah) merupakan salah satu makanan tradisional khas Aceh yang dibuat dari ikan tongkol, tuna, cakalang yang terlapisi tepung terigu dan dikeringkan dibawah sinar matahari. Pada umumnya selama penyimpanan dan pemasaran di tempat terbuka, memungkinkan ikan tersebut terkontaminasi oleh mikroba, khususnya kapang. Lilin sarang lebah mengandung senyawa flavonoid yang berguna sebagai antimikroba yang dapat menghambat mikroorganisme patogen sehingga penggunaan lilin sarang lebah pada ikan kayu (keumamah) diduga dapat menghambat aktivitas antifungi pada ikan kayu (keumamah). Antifungi atau antimikroba adalah suatu bahan yang dapat mengganggu pertumbuhan dan metabolisme mikroorganisme sehingga dapat mengendalikan mikroba maupun jamur, yaitu segala kegiatan yang dapat menghambat, membasmi, atau menyingkirkan mikroorganisme. Dengan dilakukannya studi ini diharapkan dapat diketahui apakah lilin sarang lebah dapat digunakan sebagai antifungi pada ikan kayu (keumamah), bagaimanakah konsentrasi terbaik lilin sarang lebah yang dapat digunakan sebagai antifungi, bagaimanakah perubahan yang terjadi pada ikan kayu (keumamah) selama waktu penyimpanan dengan metode organoleptik dan uji populasi kapang serta uji kadar air. Variabel yang digunakan suhu memanaskan sarang lebah $65^{\circ} \mathrm{C}$, berat ikan keumamah $400 \mathrm{gr}$, waktu perebusan ikan $45^{\circ} \mathrm{C}$. Sedangkan variabel bebas adalah konsentrasi lilin sarang lebah (0\%, 5\%, 10\%, 15\%, 20\%) dan waktu penyimpanan 15 hari dan 30 hari. Hasil penelitian menunjukkan konsentarsi 15\% lilin sarang lebah adalah konsentrasi terbaik yang dapat menghambat pertumbuhan kapang dengan kadar air 17,704, organoleptik untuk setiap spesifikasi yaitu kenampakan, aroma, rasa, tekstur masih memenuhi syarat mutu standar SNI yaitu 10, 8, 7, 9 serta jumlah total koloni kapang 2,09 CFU/gr sampai waktu penyimpanan 30 hari.
\end{abstract}

Kata kunci: Ikan kayu (keumamah), Lilin sarang lebah, Antifugi. Organoleptik, Total koloni kapang. 


\section{ABSTRACT}

Wooden fish (Keumamah) is one of Aceh's traditional foods made from tuna, tuna, skipjack coated with flour and dried in the sun. In general, during storage and marketing in the open, allowing the fish to be contaminated by microbes, especially mold. Beehive wax contains flavonoid compounds that are useful as antimicrobials that can inhibit pathogenic microorganisms so that the use of beehive wax in wood fish (genum) is thought to inhibit the antifungal activity in wood fish (genum). Antifungal or antimicrobial is a material that can interfere with the growth and metabolism of microorganisms so that they can control microbes and fungi, namely all activities that can inhibit, eradicate, or get rid of microorganisms. By doing this study it is expected to know whether beehive wax can be used as an antifungal in wood fish (common), how is the best concentration of beehive wax that can be used as an antifungal, how is the change that occurs in wood fish (common) during storage with organoleptic methods and mold population test and moisture content test. The variables used were the temperature of the honeycomb heats $65 \mathrm{oC}$, the weight of the grum fish $400 \mathrm{gr}$, the boiling time of the fish was $45 \mathrm{oC}$. While the independent variable is the concentration of beehive wax $(0 \%, 5 \%, 10 \%, 15 \%, 20 \%)$ and storage time of 15 days and 30 days. The results showed the concentration of $15 \%$ honeycomb wax is the best concentration that can inhibit the growth of molds with a water content of 17,704, organoleptic for each specification namely appearance, aroma, taste, texture still meet the quality requirements of SNI standards 10, 8, 7, 9 and the amount total mold colonies $2.09 \mathrm{CFU} / \mathrm{g}$ until 30 days of storage.

Keywords: Wooden fish (keumamah), Beehive wax, Antifugi. Organoleptic, total mold colonies. 


\section{PENDAHULUAN}

Ikan kayu (keumamah) merupakan salah satu makanan tradisional khas Aceh yang dibuat dari ikan tongkol, tuna, cakalang yang terlapisi tepung terigu dan dikeringkan dibawah sinar matahari (Djarijah, 1995). Cara pengawetan ikan secara tradisional menyebabkan ikan menjadi keras, dengan warna menjadi kehitaman menyerupai kayu, dan dapat bertahan lama. Kualitas ikan kayu tergantung pada proses pengolahan dan cahaya matahari selama pengeringan (Moeljanto, 1992).

Pada umumnya selama penyimpanan dan pemasaran di tempat terbuka, memungkinkan ikan tersebut terkontaminasi oleh mikroba, khususnya kapang. Keberadaan kapang pada permukaan ikan kayu sebagai kontaminan terjadi karena tepung terigu yang digunakan sebagai pelapis ikan. Pemakaian tepung terigu sebagai pelapis dimaksudkan agar air yang terkandung di dalam ikan terserap oleh tepung sehingga ikan dapat bertahan lama. Menurut Belitz dan Grosch (1999), tepung terigu merupakan karbohidrat yang dapat menyerap air. Hal ini sesuai dengan pernyataan Fitasari (2009) bahwa penambahan tepung terigu menyebabkan sebagian besar air pada bahan akan terserap kedalam pati (amilum), sehingga pada kondisi lembab dan basah memungkinkan terjadi pertumbuhan kapang yang tidak dinginkan atau sebagai kontaminan. Kapang yang sering menyerang tepung terigu adalah kapang amilolitik yaitu kapang yang mampu menghidrolisis amilum menjadi senyawa yang lebih sederhana terutama dalam bentuk glukosa (Fardiaz, 1992).

Hasil penelitian terdahulu (Safika, 2008) dalam penelitian resmila dewi, dkk tentang aktivitas antifungi kitosan dari kulit udang menunjukkan bahwa hampir semua ikan kayu dari pasar Banda Aceh dan Lhokseumawe banyak terkontaminasi oleh Aspergillus. Selain itu, berdasarkan penelitian yang dilakukan oleh Putri (2015) menunjukkan bahwa ikan kayu yang yang dijual di 5 pasar tradisional Kota Banda Aceh positif mengandung formalin. Resiko kesehatan yang ditimbulkan jika konsumen mengkonsumsi produk yang telah terkontaminasi oleh kapang patogen maupun produk yang mengandung formalin sangat berbahaya karena bersifat karsinogen. Pengunaan formalin sangat berbahaya untuk kesehatan. Formalin bersifat akumulatif dalam tubuh. Konsumsi secara terus-menerus dalam dosis rendah menimbulkan dampak yang baru terlihat dalam jankga panjang (Anwar dkk, 2009). Paparan jangka panjang terhadap formalin diketahui berkaitan dengan peningkatan risiko terjadinya kanker pada hidung, sinus, dan paru-paru. Karsinogensi formalin meliputi perlekatan pada DNA, genotoksinitas dan perubahan sitotoksik (Lilyea, 2012).

Hasil penelitian terdahulu Resmila dewi, dkk (2016), menunjukkan bahwa ikan kayu yang diperoleh dari pasar banda Aceh terkontaminasi oleh aspergillus. Kitosan hasil ekstraksi dari kulit udang mempunyai aktivitas antifungi terhadap aspergillus. Berdasarkan uji organoleptik dan analisis popuasi kapang, perendaman ikan selama 60 dan 75 menit dalam larutan kitosan 1,5\% (b/v) menghasilkan ikan kayu layak untuk dikomsumsi sehingga dapat digunakan sebagai pengawet.

Bahan lainnya yang dapat digunakan untuk dijadikan antifungi adalah lilin sarang lebah. Lilin sarang lebah berasal dari sarang lebah yang mengandung 50\% senyawa resin (flavonoid dan asam fenolat), 30\% lilin lebah, 10\% minyak aromatic, $5 \%$ polen dan $5 \%$ berfungsi sebagai senyawa aromatic (Pietta, 2002). Lilin sarang lebah mengandung senyawa organik hidrokarbon jenuh, ester dan alkohol. 
Penggunaan lilin sarang lebah pada ikan kayu dapat dilakukan dengan cara melapisi (coating) ikan kayu dengan lilin sarang lebah. Sarang lebah mengandung senyawa flavonoid yang berguna sebagai antimikroba yang dapat menghambat mikroorganisme patogen (Manoi, 2009).

Hasil penelitian Hartini (2017), menunjukkan bahwa aktivitas antifungi ekstrak metanol sarang lebah yang terdiri dari kantong madu, kantong polen, propolis dan kantong telur memiliki daya hambat terhadap kapang candida albicans, semakin tinggi konsentrasi semakin besar pula daya hambat suatu ekstrak terhadap pertumbuhan candida albicans.

Sarang lebah banyak mengandung senyawa asam fenolat, flavonoid dan tanin (Yuliana dkk, 2015). Berdasarkan penelitian Yuliana (2015), bahwa ekstrak etanol sarang lebah, memilki potensi sebagai antimikrobia alami untuk menghambat sekaligus membunuh pertumbuhan kapang jenis candida albacans. Senyawa aktif yang berperan dalam penghambatan pertumbuhan mikrobia potagen adalah gugus hidroksil yang menyebabkan perubahan komponen organik dan transport nutrisi sehingga mengakibatkan efek toksik pada mikroba potagen.

Berdasarkan latar belakang diatas, peneliti mencoba memanfaatkan sarang lebah sebagai antifungi pada ikan kayu (keumamah) dalam suatu upaya pencegahan kontaminasi kapang sehingga dapat meninggkatkan daya simpan dengan menghambat pertumbuhan mikroorganisme potagen yang mengacu pada standar food grade.

\section{TINJAUAN PUSTAKA}

\subsection{Ikan Kayu (Keumamah)}

Ikan kayu (keumamah) merupakan salah satu makanan tradisional khas Aceh yang dibuat dari ikan tongkol (Euthynnus affinis) yang terlapisi tepung terigu dan dikeringkan dibawah sinar matahari (Djarijah, 1995). Cara pengawetan ikan secara tradisional menyebabkan ikan menjadi keras, dengan warna menjadi kehitaman menyerupai kayu, dan dapat bertahan lama. Kualitas ikan kayu tergantung pada proses pengolahan dan cahaya matahari selama pengeringan (Moeljanto, 1992). Selain memiliki rasa yang lezat dan unik, ikan ini terbuat dari ikan tuna, tongkol, dan cakalang yang telah direbus, kemudian dikeringkan dan diiris-iris kecil. Berikut komposisi kimia ikan tongkol (termasuk ikan tuna):

Tabel 2.1 Komposisi Kimia Ikan Tongkol (Termasuk Ikan Tuna) Dalam 100 G

\begin{tabular}{|l|c|c|}
\hline \multicolumn{1}{|c|}{ Zat gizi } & Satuan & Kadar \% \\
\hline Air & $\mathrm{g} \%$ & 68 \\
\hline Protein & $\mathrm{G}$ & 26 \\
\hline Energi & Kalori & 180 \\
\hline Karbohidrat & $\mathrm{G}$ & 0 \\
\hline Serat kasar & $\mathrm{G}$ & 0 \\
\hline Lemak & $\mathrm{G}$ & 6 \\
\hline Kolesterol & $\mathrm{Mg}$ & 430 \\
\hline Kalsium & $\mathrm{Mg}$ & 9 \\
\hline
\end{tabular}




\begin{tabular}{|l|c|c|}
\hline Besi & $\mathrm{Mg}$ & 1,15 \\
\hline Mangan & $\mathrm{Mg}$ & 57 \\
\hline Potasium & $\mathrm{Mg}$ & 44 \\
\hline Sodium & $\mathrm{Mg}$ & 0,68 \\
\hline Zink & $\mathrm{Mg}$ & 740 \\
\hline Vitamin A & $\mathrm{Re}$ & 0,27 \\
\hline Tiamin & $\mathrm{Mg}$ & 1,13 \\
\hline Ribovlaavin & $\mathrm{Mg}$ & 0,28 \\
\hline Niasin & $\mathrm{Mg}$ & 9,28 \\
\hline
\end{tabular}

Sumber: Whitney, dkk, 1998.

2.2 Sarang Lebah Dan Lilin Lebah Lebah merupakan sekelompok besar serangga yang dikenal karena suka hidup berkelompok meskipun sebenarnya tidak semua lebah bersifat demikian. Di dunia terdapat kira-kira 20.000 spesies lebah dan dapat ditemukankan disetiap benua, kecuali antartika. Sebagai serangga, ia mempunyai tiga pasang kaki dan dua pasang sayap. Lebah membuat sarangnya di atas bukit, dipohon kayu dan pada atap rumah. Sarangnya dibangun dari malam yang terdapat dalam badanya (Ensiklopedia, 2007).

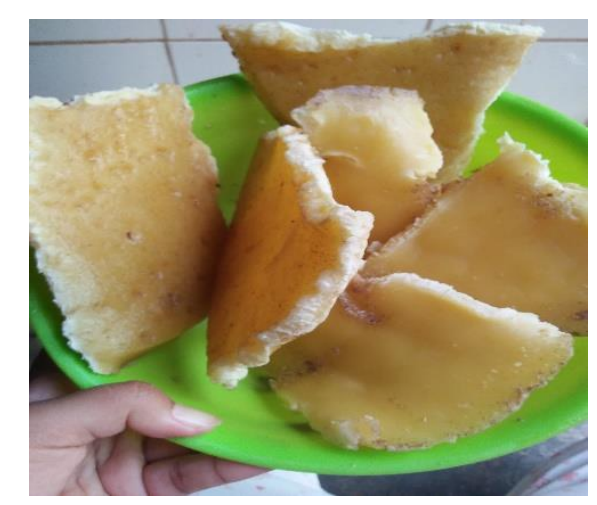

Lilin lebah adalah lilin atau malam yang diproduksi dari sarang lebah. Umumnya tersusun atas dari ester asam lemak dan berbagai senyawa alkohol rantai panjang. Struktur formula kasar dari lilin lebah yaitu $\mathrm{C}_{15} \mathrm{H}_{31} \mathrm{COOC}_{30} \mathrm{H}_{61}$. Komponen utamanya berupa palmitat, palmitoleat, dan ester dari asam oleat dengan panjang rantai antara 30 hingga 32 karbon yang terdiri dari senyawa alifatik alkohol. Rasio triacontanyl palmitate $\mathrm{CH}_{3}\left(\mathrm{CH}_{2}\right)_{29} \mathrm{O}-\mathrm{CO}-\left(\mathrm{CH}_{2}\right)_{14} \mathrm{CH}_{3}$ terhadap cerotic acid $\mathrm{CH}_{3}\left(\mathrm{CH}_{2}\right)_{24} \mathrm{COOH}$, adalah 6:1. Nilai saponifikasi untuk lilin lebah Eropa adalah 3-5, sedangkan lilin lebah Asia 8-9. Lilin lebah memiliki titik lebur yang rendah, antara 62-64 derajat Celcius. Jika dipanaskan hingga di atas 85 derajat Celcius, perubahan warna terjadi Lilin lebah mulai menyala pada temperatur 204.4 derajat Celcius. Massa jenis lilin lebah pada temperatur 15 derajat Celcius $15^{\circ} \mathrm{C}$ adalah 958 to $970 \mathrm{~kg} / \mathrm{m}^{3}$ (https://id.wikipedia.org/wiki/Lilin_lebah.

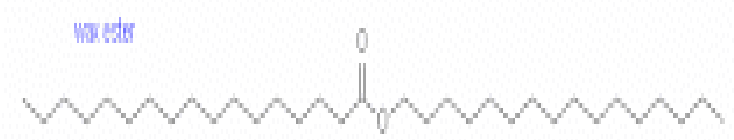

(http://lipidlibrary.aocs./org/lipids/waxes/index.ht) 
Lilin lebah ini pada dasarnya merupakan sejenis lilin atau malam yang diproduksi oleh lebah. Dimana terdapat kemungkinan bahwa lebah mengorbankan produksi madu mereka untuk menghasilkan lilin lebah ini. Lilin lebah sendiri penggunaannya memiliki banyak sekali manfaat. Selain itu, sarang lebah mengandung senyawa flavonoid yang berguna sebagai antimikroba yang dapat menghambat mikroorganisme patogen (Manoi, 2009).

\subsection{Antifungi}

Fungi adalah organisme eukariot karena memiliki membran inti pada selnya, sehingga banyak kesamaan biokimiawi antara sel jamur dengan sel manusia. Sebuah jamur adalah anggota kelompok besar eukariotik organisme yang meliputi mikroorganisme seperti ragi dan jamur, serta lebih akrab jamur. Antifungi adalah senyawa yang digunakan untuk pengobatan penyakit yang disebabkan oleh jamur. Antifungi/antimikroba adalah suatu bahan yang dapat mengganggu pertumbuhan dan metabolisme mikroorganisme. Pemakaian bahan antimikroba merupakan suatu usaha untuk mengendalikan bakteri maupun jamur, yaitu segala kegiatan yang dapat menghambat, membasmi, atau menyingkirkan mikroorganisme.

Antimikroba menghambat pertumbuhan mikroba dengan cara bakteriostatik atau bakterisida. Hambatan ini terjadi sebagai akibat gangguan reaksi yang esensial untuk pertumbuhan. Reaksi tersebut merupakan satu-satunya jalan untuk mensintesis makromolekul seperti protein atau asam nukleat, sintesis struktur sel seperti dinding sel atau membran sel dan sebagainya. Antibiotik tertentu dapat menghambat beberapa reaksi, reaksi tersebut ada yang esensial untuk pertumbuhan dan ada yang kurang esensial (Suwandi 1992).

Penghambatan sintesis asam nukleat dan protein jamur, merupakan mekanisme yang disebabkan oleh senyawa turunan pirimidin. Efek antijamur terjadi karena senyawa turunan pirimidin mampu mengalami metabolisme dalam sel jamur menjadi suatu antimetabolit. Metabolik antagonis tersebut kemudian bergabung dengan asam ribonukleat dan kemudian menghambat sintesis asam nukleat dan protein jamur. Penghambatan mitosis jamur, efek antijamur ini terjadi karena adanya senyawa antibiotik griseofulvin yang mampu mengikat protein mikrotubuli dalam sel, kemudian merusak struktur spindle mitotic dan menghentikan metafasa pembelahan sel jamur (Sholichah 2010).

\section{METODOLOGI PENELITIAN}

\subsection{Tempat dan Waktu Pelaksanaan}

Tempat penelitian dilaksanakan di laboratorium Jurusan Teknik Kimia Universitas Malikussaleh, Lhokseumawe dan Labkes, Kota Lhokseumawe.

\subsection{Peralatan yang digunakan}

Peralatan yang digunakan pada penelitian ini meliputi:

1. Hot plate

2. Beaker glass

3. Pengaduk

4. Tempat penampung

5. Pisau

6. Termometer 
7. Tempat jemuran ikan

8. Timbangan

\subsection{Bahan yang digunakan}

1. Air (aquades)

2. Sarang lebah

3. Ikan tongkol

4. Garam

\subsection{Variabel Penelitian}

Adapun variabel percobaan yang dipergunakan pada peneitian ini adalah:

\subsubsection{Variabel Tetap}

a. Suhu memanaskan sarang lebah $65^{\circ} \mathrm{C}$

b. Berat ikan keumamah $400 \mathrm{gr}$

c. Waktu perebusan ikan 45 menit

\subsubsection{Variabel Bebas}

a. Konsentrasi lilin sarang lebah 5, 10, 15, $20 \%$ dengan $0 \%$ sebagai kontrol

b. Waktu penyimpanan 15,30 hari

\subsubsection{Variabel Terikat}

a. Uji organoleptik (warna, rasa, aroma, tekstur)

b. Kadar air

c. Analisa populasi kapang

\section{HASIL DAN PEMBAHASAN}

\subsection{Total Koloni Kapang}

Berdasarkan pengamatan nilai total koloni kapang diperoleh jumlah koloni kapang ikan keumamah selama penyimpanan 15 hari dan 30 hari dapat dilihat pada gambar dibawah ini :

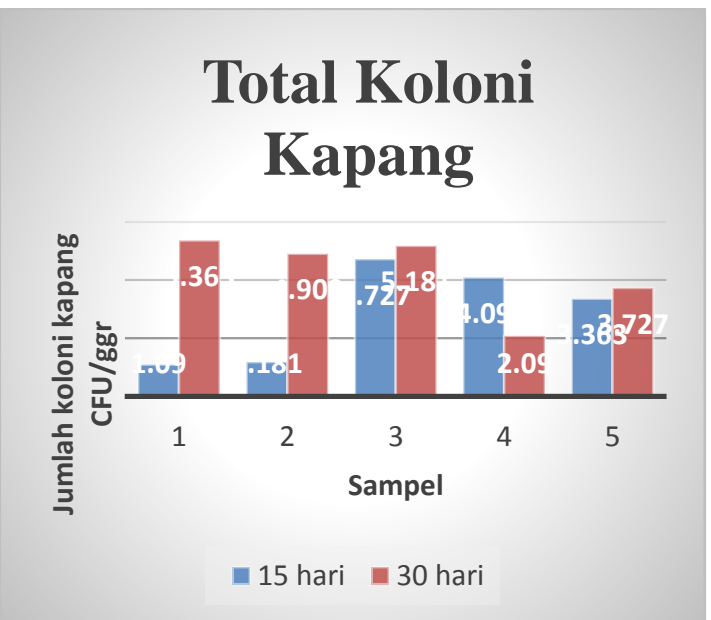

Gambar 4.5 Nilai Total Koloni Kapang Ikan Keumamah Penyimpan 15 Hari Dan 30 Hari 
Gambar diatas terlihat bahwa jumlah koloni kapang banyak mengalami peningkatan pada penyimpanan 30 hari pada suhu kamar. Hal ini disebabkan karena ikan keumamah sudah terkontaminasi dengan udara dalam jangka waktu yang lebih lama sehingga tersedianaya oksigen untuk kebutuhkan metabolisme dari kapang, sehingga kapang sangat cepat untuk berkembang. Selain itu juga pengaruh dari suhu lingkungan yang membuat daging ikan keumamah menjadi lembab. Syarat mutu yang ditetapkan oleh Standar Mutu Nasional Indonesia untuk nilai kapang maksimum adalah $5 \times 10^{3}$ CFU/gr (Aninimous, 1987).

\section{Identifikasi Kapang}

Hasil pengamatan struktur kapang pada media Potato Dextrose Agar (PDA), dapat dilihat penampakkan kapang secara makrokopis dan mikrokopis ikan keumamah yang dilapisi lilin sarang lebah. Hasil pengamatan dengan mengacu pada buku petunjuk klasifikasi menurut Barnett (1972). Dapat dilihat pada gambar 4.5 ini:

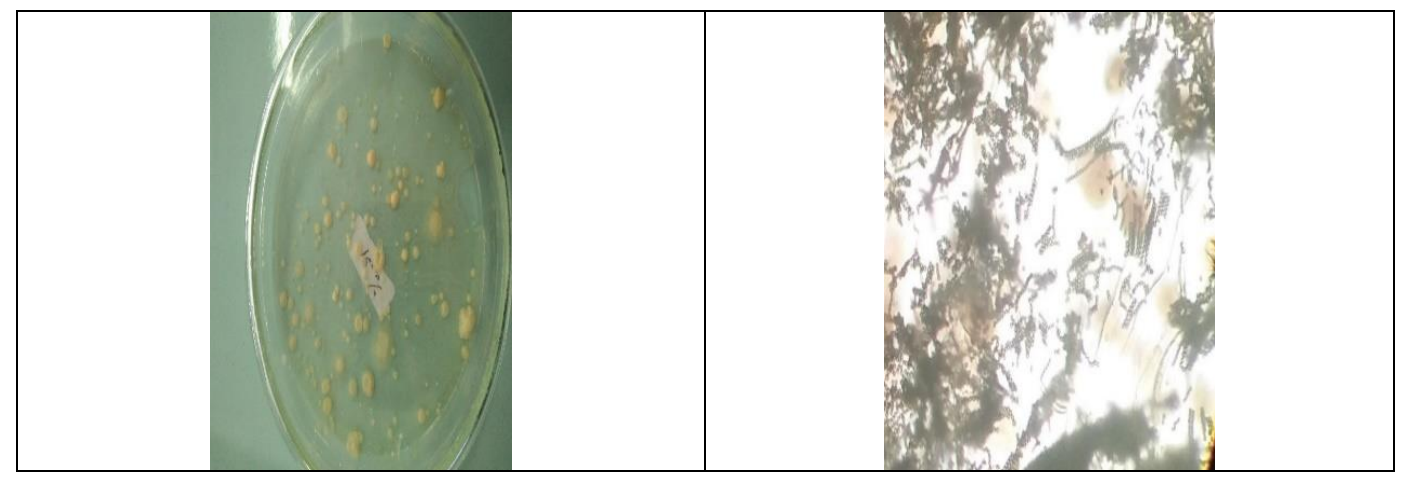

a. Makrokopis

b. Mikrokopis

Gambar 4.5 Jenis Jamur Fusarium sp.

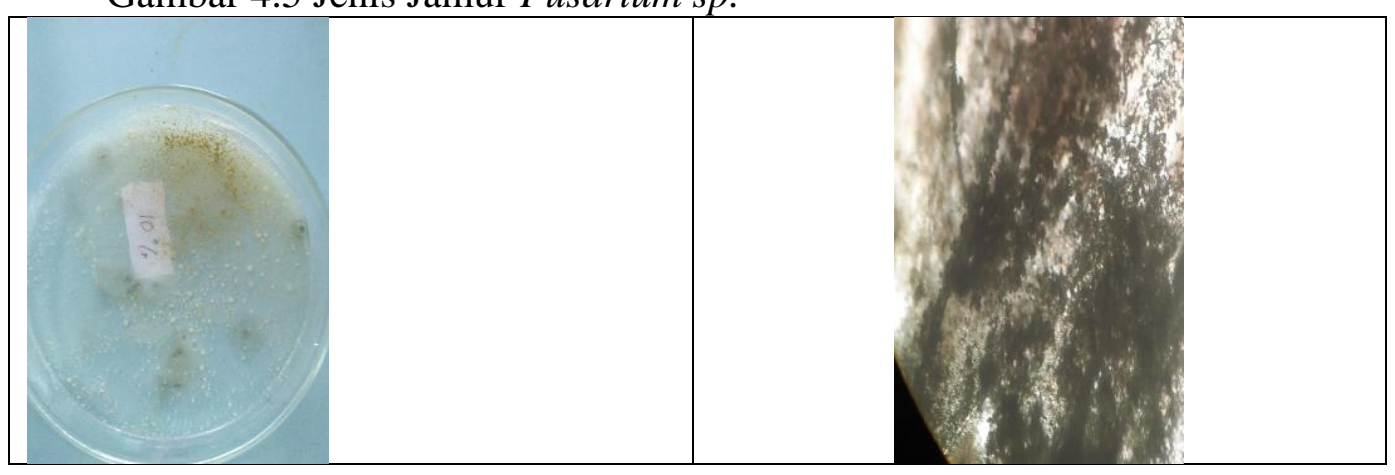

a.Makrokopis

b. Mikrokopis

Gambar 4.6 Jenis Jamur Aspergillus sp.

\subsection{Organoleptik}

\begin{tabular}{|c|c|c|c|c|c|}
\hline Spesifikasi & \multicolumn{6}{|c|}{ 2 Minggu Sebelum Penyimpanan } \\
\hline $\begin{array}{c}\text { Konsentrasi } \\
(\boldsymbol{\%})\end{array}$ & $\mathbf{0}$ & $\mathbf{5}$ & $\mathbf{1 0}$ & $\mathbf{1 5}$ & $\mathbf{2 0}$ \\
\hline Kenampakan & 10 & 13 & 13 & 13 & 13 \\
\hline
\end{tabular}




\begin{tabular}{|c|c|c|c|c|c|}
\hline Aroma & 12 & 11 & 12 & 11 & 11 \\
\hline Rasa & 11 & 11 & 11 & 10 & 10 \\
\hline Tekstur & 12 & 12 & 13 & 13 & 13 \\
\hline
\end{tabular}

\begin{tabular}{|c|c|c|c|c|c|}
\hline Spesifikasi & \multicolumn{6}{|c|}{ 4 Minggu Setelah Penyimpanan } \\
\hline $\begin{array}{c}\text { Konsentrasi } \\
(\%)\end{array}$ & $\mathbf{0}$ & $\mathbf{0}$ & $\mathbf{0}$ & $\mathbf{0}$ & $\mathbf{0}$ \\
\hline Kenampakan & 5 & 6 & 7 & 10 & 6 \\
\hline Aroma & 5 & 5 & 7 & 8 & 6 \\
\hline Rasa & 0 & 0 & 0 & 7 & 0 \\
\hline Tekstur & 6 & 6 & 7 & 9 & 7 \\
\hline
\end{tabular}

\section{a. Kenampakan}

Dari nilai tersebut dapat dilihat ikan kayu terjadi penurunan nilai organoleptik dilihat dari nilai ketidak disukaan oleh panelis. Menurut winarno, 1993 menyatakan bahwa perubahan warna yang terjadi pada ikan kayu dapat menentukan apakah ikan kayu tersebut masih baik atau tidak. Pemilihan warna pada produk bahan pangan merupakan salah satu pertimbangan yang utama dalam menentukkan kondisi pangan.

\section{b. Aroma}

Dari nilai ditabel daoat dilihat bahwa ikan kayu mengalami penurunan nilai aroma, ini diakibatkan oleh timbulnya bau tambahan yang kuat, tercium bau amoniak dan tengik pada produk ikan kayu sehingga menyebabkan produk ikan kayu dari segi bau sudah tidak disukai panelis (SNI 2009). Widiastuti, 2007 menyatakan kehadiran mikroorganisme pada ikan juga mengakibatkan perubahan bau. Bau tersebut timbul akibat timbulnya amoniak $\left(\mathrm{NH}_{3}\right)$ pada degradasi protein dan gas $\mathrm{H}_{2} \mathrm{~S}$. Nilai aroma menunjukkan bahwa ikan kayu yang perlakuan konsentrasi $15 \%$ setelah mengalami penyimpanan 4 minggu, nilai oerganoleptik dari segi aroma masih disukai panelis. Nilai persyaratan mutu ikan kayu menurut Standar Nasional Indonesia (SNI, 2009) minimal 7.

\section{c. Rasa}

Dari nilai di tabel diatas menunjukan bahwa ikan kayu yang disimpan selama 4 minggu menglami penurunan nilai organoleptik, penurunan ini menurun pada konsentrasi 0, 5, 10 dan $20 \%$. Hal ini dikarenakann ikan sudah ditumbuhi oleh jamur sehingga tingkat kesukaan penalis terhadap cita rasa menurun. Menurut manoi, 2009 menyatakan bahwa sarang lebah mengandung senyawa flavonoid yang berguna sebagai antimikroba yang dapat menghambat pertumbhan mikroorganisme patogen. Rasa yang tidak enak disebabkan oleh faktor lingkungan yang mendukung 
mikroba selama penyimpanan misalnya kadar air, suhu $\mathrm{O}_{2}$ sehingga mikroba akan merusak daging, dan tingkat kesukaan konsumen menurun.

\section{d. Tekstur}

Dari tabel di atas menunjukkan bahwa nilai organoleptik tekstur tertinggi adalah 9 dengan perlakuan $15 \%$ lilin sarang lebah dan setelah mengalami penyimpanan selama 4 minggu, sedangkan nilai terendah organoleptik tekstur pada konsentrasi $0 \%$ yaitu 6 . Kombinasi pertumbuhan jamur pada bagian permukaan daging ikan dan aktivitas mikroba pada bagian dalam daging ikan mempercepat terjadinya kemunduran mutu ikan (Anonimous, 2010). Selain pengaruh kadar air menurut bustan dkk, 1982 dalam tribowo, 1985 aksi bakterial maupun enzim mengakibatkan degradasi jaringan pengikat yang menyebabkan penurunan tekstur ikan. Tekstur ikan kayu yang direkomendasikan menurut Standar Nasional Indonesia (SNI, 2009) yaitu minimal 7.

\subsection{Kadar Air}

\begin{tabular}{|c|c|c|c|}
\hline $\begin{array}{c}\text { Konsentrasi Lilin } \\
\text { Sarang Lebah } \\
(\mathbf{\%})\end{array}$ & $\begin{array}{c}\text { Berat Awal Ikan } \\
\text { (gr) }\end{array}$ & $\begin{array}{c}\text { Berat Akhir } \\
\text { Ikan (gr) }\end{array}$ & Kadar Air (\%) \\
\hline 0 & 400 & 336,05 & 15,987 \\
\hline 5 & 403 & 336,26 & 16,560 \\
\hline 10 & 407,13 & 336,75 & 17,286 \\
\hline 15 & 409,78 & 337,23 & 17,704 \\
\hline 20 & 409,98 & 337,76 & 17,681 \\
\hline
\end{tabular}

Penurunan kadar air dari kelima perlakuan konsentrasi diduga karena suhu dan lamanya pengeringan. Menurut wibowo (2000), dijelaskan bahwa pada bahan pangan yang dipanaskan, total air/cairan yang keluar dari produk akan semakin meningkat dengan semakin meningkatnya temperatur dan lama proses pengeringan.

Perbedaan kadar air dari kelima perlakuan diduga karena konsentrasi berat lilin sarang lebah yang digunakan untuk melapisi ikan kayu sehingga apabila dipanaskan atau dikeringkan dengan suhu dan waktu proses yang sama, konsentrasi tertinggi akan terkandung kadar air yang tinggi pula. Selain itu, Berkurangnya kadar air produk dapat menyebabkan komponen protein, lemak dan abu menjadi meningkat, hal ini diduga karena komponen tersebut masih terikat dalam air (Ahmed et al, 2010).

\section{KESIMPULAN DAN SARAN}

\subsection{Kesimpulan}

1. Berdasarkan hasil dari nilai kadar air ikan keumamah yang dilapisi lilin sarang lebah dengan konsentrasi yanng berbeda-beda yaitu 0\% 5\% 10\% 15\% 20\%, diantara konsentrasi tersebut yang termasuk dalam kriteria mutu SNI (Standar Nasional Indonesia) yang baik pada konsentrasi 15\% yaitu dengan kadar air 17,704 $\%$.

2. Berdasarkan hasil penelitian organoleptik dari panelis selama penyimpanan 2 minggu dan 4 minggu. Pada penyimpanan 2 minggu hasil yang didapat hampir semua spesifikasi yang diuji disukai panelis, nilai yang didapatkan telah memenuhi standar SNI. Sedangkan pada penyimpanan 4 minggu nilai yang didapat untuk setiap spesifikasi yang diuji hampir semua sudah tidak disukai panelis dan konsentrasi $15 \%$ adalah konsentrasi terbaik yang disukai panelis pada penyimpana 4 minggu. Nilai organoleptik menurut SNI yang memenuhi syarat yaitu 7 . 
3. Total koloni kapang pada ikan kayu atau keumamah yang dilapisi lilin sarang lebah dengan penyimpanan 30 hari adalah konsentrasi $15 \%$ dan $20 \%$ yaitu 2,090 CFU/gr dan 3,727 CFU/gr masih memenuhi standar SNI. Kapang yang teridentifikasi pada ikan kayu atau keumamah yang dilapisi lilin sarang lebah adalah Fusarium sp dan Aspergillus sp.

4. Dari hasil yang didapat, lilin sarang lebah dapat digunakan untuk menghambat pertumbuhan kapang pada ikan kayu atau keumamah selama masa penyimpanan 30 hari.

\subsection{Saran}

Dari hasil yang didapatkan dari penelitian ini menunjukkan bahwa perlu adanya perluasan pemahaman tentang lilin sarang lebah agar dapat memberi nilai tambah selain digunakan sebagai antifungi pada ikan kayu atau keumamah.

\section{DAFTAR PUSTAKA}

Ahmed.,et al. 2010. Impact of Service Quality on Custumers Satisfaction: Empirical evidence from telecom sector of Pakistan. Pakistan. Journal of Contemporary Research InBusiness, Vol. 1 No.12, 2010.

Anwar, Faisal dan Ali Khomsan. 2009. Makanan Tepat Badan Sehat. Jakarta: Hikmah.

Anonimous,, 1987. Penentuan Aerobic Plate Count. Standar Pertanian Indonesia Bidang Perikanan Direktorat Jenderal Perikanan Jakarta.

Anonimous., 2010. Studi Pengembangan Dan Penerapan Teknik Pengasapan Ikan Tongkol Di Kabupaten Natuna. Laporan Akhir BPP-PSPL UNRI.

Belitz, H. D. dan Grosch, W. 1999. Food Chemistry. England: Library of Conggres Cataloging Publication Data.

Barnett,H.L. dan Hunter, B.B. 1972.Ilustrated Genera of Imperfect Fungi. Fourth Edition. APS Press. America.

Djarijah, A.S, (1995). Pakan Alami. Yogyakarta : Kanisius.

Dewi Resmila, dkk. 2016. Aktivitas Antifungi Kitosan Terhadap Kapang kontaminan Pada Ikan Kayu. Universitas Gadjah Mada, Yogjakarta.

Ferdiaz, S., 1992. Mikrobiologi Pangan I. Gramedia Pustaka Utama. Jakarta.

Fitasari, E. 2009. Pengaruh Tingkat Penambahan Tepung Terigu Terhadap Kadar Air, Kadar Lemak, Kadar Protein, Mikrostruktur, dan Mutu Organoleptik Keju Gouda. Jurnal Ilmu dan Teknologi Hasil Ternak. 4(2) : 17-29.

Https://id.wikipedia.org/wiki/Lilin_lebah, diakses 2 juli 2018

Http://lipidlibrary.aocs./org/lipids/waxes/index.htm, diakses 11 juli 2018

Manoi F. 2009. Binahong (Anredera cordifolia) sebagai Obat. Warta Penelitian dan Pengembangan Tanaman Industri. 15(1):3-5.

Moeljanto, 1992 pengawetan dan pengolahan hasil perikanan, jakarta, penebar swadya.

Pietta, PG. 2002. Flavonoid as antioxidant. Jurnal of natural product. 63(7) july. 2000:, 1035-1042.

Putri, Aafiyah. 2015. Analisis Pengaruh Perubahan Profitabilitas Terhadap Perubahan Saham Pada Perubahan Manufaktur Yang Terdaftar Di Bursa 
Efek Indonesia Tahun 2009-2013. Skripsi. Universitas Hasanuddin: Makasar.

Safika. 2008. Korelasi aspergillus flavus dengan konsentrasi aflatoksin BI pada ikan kayu J. Ked Hewan. 2(2):168-167.

Sholihah. 2010. Upaya Meningkatkan Kemampuan Kognitif Dalam Pembelajaran Sains Melalui Permainan Warna. Skripsi, Ums

Wibowo, Singgih. 2000. Pembuatan Bakso Ikan dan Bakso Daging. Penebar Swadaya. Jakarta.

Widiastuti, I.M.2007. Sanitasi dan Mutu Kesegaran Ikan Konsumsi Pada Pasar Tradisional di Kotamadya Palu. Jurnal. Agroland 14 (1): 77-81 ISSN: 0854-641x.

Winarno, F. G. 1993. Pangan, Gizi, Teknologi dan Konsumen. Jakarta. Gramedia Pustaka Utama.

Whitney, et al. 1998 dalam Nurahman dan J.T. Isworo. 2010. Peran Tawasterhadap Peruraian Protein Ikan Tongkol. (Skripsi). Unimus. $285 \mathrm{hlm}$ 